Journal of Environmental Science and Public Health

doi: $10.26502 /$ jesph. 96120022

Volume 1, Issue 4

Research Article

\title{
Spiders of Taleigao Plateau, Goa, India
}

\author{
Rupali Pandit and Pai IK* \\ Department of Zoology, Goa University, Goa, India \\ *Corresponding Author: I.K. Pai, Department of Zoology, Goa University, Goa-403 206, India, Tel: \\ 08326519047; E-mail: ikpai@unigoa.ac.in
}

Received: 21 September 2017; Accepted: 02 October 2017; Published: 09 October 2017

\begin{abstract}
Spiders have utilitarian value. The present study is the first comprehensive documentation of the spider fauna from the Taleigao plateau, Goa, India and has revealed occurrence of 74 species of spiders belonging to 17 families. The investigation was carried out for 8 months from July 2016 to February 2017. Through this research, some new families, genera and species were reported for Goa, some of which are endemic to India. The methods included active searching and visual surveys. Salticids were the most dominant and diverse group of spiders in the study, yet it is one of the least studied families in India. The spiders such as Hersilia savignyi, Plexippus petersi were the predominant species of spiders in the study area. The spiders belonged to 9 foraging guilds. The present study has emphasized the need for conservation of this ecosystem by characterizing species diversity and highlighting endemic species. It has definitely filled the lacuna of spider study in Goa to some extent and forms a basis for further investigations on the spider diversity in the areas in and around the state. Future research on the spiders of Taleigao plateau can certainly expect innumerable discoveries.
\end{abstract}

Keywords: Spiders; Plateau; India; Endemic; Dominant; Diverse; Guilds; Conservation

\section{Introduction}

Class Arachnida of Phylum Arthropoda includes air breathing arthropods, with their head and thorax usually fused together, forming a cephalothorax which is provided with four pairs of legs and lack wings and antennae [1]. Today, class Arachnida comprises of 11 orders and approximately 640 families, 9000 genera and 93,000 described species 
[1, 2]. Spiders (Order Araneae) are the largest order of Arachnids and rank seventh in total species diversity among all other groups of organisms. They are ancient animals with a history going back over 350 million years [3].

Spiders represent one of the most important components of global biodiversity. They are abundant and widespread in almost all ecosystems and play a significant role in ecology by being exclusively predatory thereby maintaining the ecological equilibrium. Spiders are also good indicators of environmental health. They play important roles in the dynamics of a specific habitat and are sensitive to habitat loss, climatic change and environmental upheavals [3]. The ubiquity, diversity and ecological role of spiders make them a promising focal group [4]. However, despite their fundamental roles in most natural ecosystem, they have largely been ignored in conservational studies.

The current world list of spiders includes 46,879 species under 4062 genera distributed over 112 families [5]. The final count in India is represented by 1686 species belonging to 438 genera of 61 families [6, 7], while from Goa 39 species contained in 28 genera from 10 families were last reported [8].

Spiders are extremely abundant throughout the country, but the knowledge of the Indian spiders is extremely fragmentary [9]. Western Ghats region is one of the regions rich in biodiversity and endemic species and has been internationally recognized as a biodiversity hotspot. Spiders being a less charismatic species and due the scarcity of biologists studying spiders, research on the spiders of India in general and Western Ghats in particular remain scant.

The present study was carried out on Taleigao plateau, Goa. Goa is a unique region characterized by the coastal belt, but also owing its uniqueness to large laterite and basaltic plateaus on the mountain crests of Western Ghats. Earlier floristic surveys revealed that the plateaus in Goa harbor the largest number of endemic plant species of the Western Ghats, especially herbs [10]. However, no work has been done on the fauna of this region except for avifaunal studies $[11,12]$. All the same, most of the plateaus in the region are already ecologically dabbled, without any prior serious environmental impact assessment.

\section{Materials and Methodology}

\subsection{Study area}

The present study was conducted for 8 months, i.e. from July 2016 - February 2017 on Taleigao Plateau with geographical location between $15^{\circ} 27^{\prime} 15^{\prime} \mathrm{N}$ and $17^{0} 50^{\prime} 00^{\prime \prime} \mathrm{E}$ (Figure 1). The plateau is about $8 \mathrm{~km}$ from Panjim, capital city of Goa. It is an east west trending lateritic table land spread over an area of approximately 296ha. Most of it is occupied by many semi / Government establishments and residential tenements. Its central zone houses the Goa University campus spanning 173 ha of the total area. Vegetation mainly consisted of moist deciduous type mixed with evergreen species. Extensive patches of grasslands on the lateritic rocky outcrops are interspersed by large thickets of shrubs and trees. 
Taleigao being in the tropical zone and near the Arabian sea the climate is warm and humid for most of the year, with atmospheric temperatures ranging from 21 to $37^{\circ} \mathrm{C}$. The humidity ranges from 60 to $95 \%$.

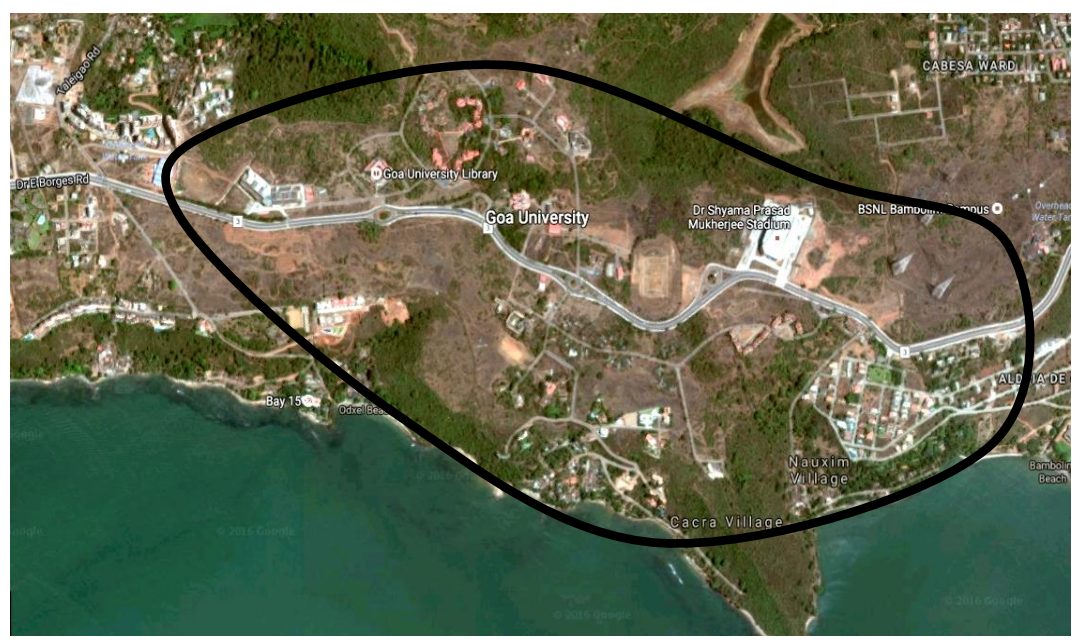

Figure 1: Study area.

\subsection{Collection and preservation of sample}

For the study, spiders were looked for in a variety of habitats in the plateau such as human dwellings, buildings, gardens, fallow land and around water bodies like ponds, tanks and the intertidal rocky shore. Specimens were also looked for under stones and loose bark, in leaf litter and flowers.

Methods included-visual searching for the spiders as far distinct vision is possible. Pitfall trapping was used to trap all possible spiders moving in that area. Ground search-hand collection, was done under leaf litter, fallen or dry wood whereas some spiders were hand collected. Sweep netting was done for the foliage dwelling spiders covering the herbs and shrubs in the area. Beating trap was done with a wooden stick and an inverted umbrella placed under the trees to catch the spiders which were unable to reach or seen hanging above. Vegetation beating and litter sampling were among the other methods.

When a spider was located, it was photographed in its microhabitat with Canon EOS 500D, 18-55 mm lens, with attached magnifying lenses. The spiders were captured in airtight plastic collection containers, and then were preserved in storage containers with $70 \%$ ethanol. Spiders were picked and transferred using forceps. Feather weight forceps were preferred to reduce damage (Photos 1-9).

\subsection{Identification}

The spiders were examined under a binocular microscope and identified with the help of identification keys by [13, 14], online literature and other resources. The taxonomy and nomenclature followed is as per the world spider catalogue [5]. 


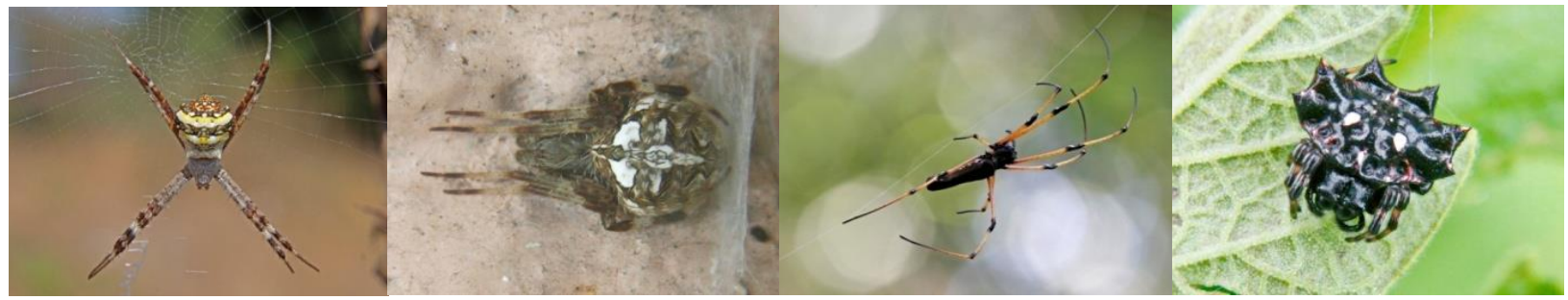

Photos 1: Araneidae: Argiope anasuja, Neoscona mukerjei, Nephila kuhlii, Telacantha sp.
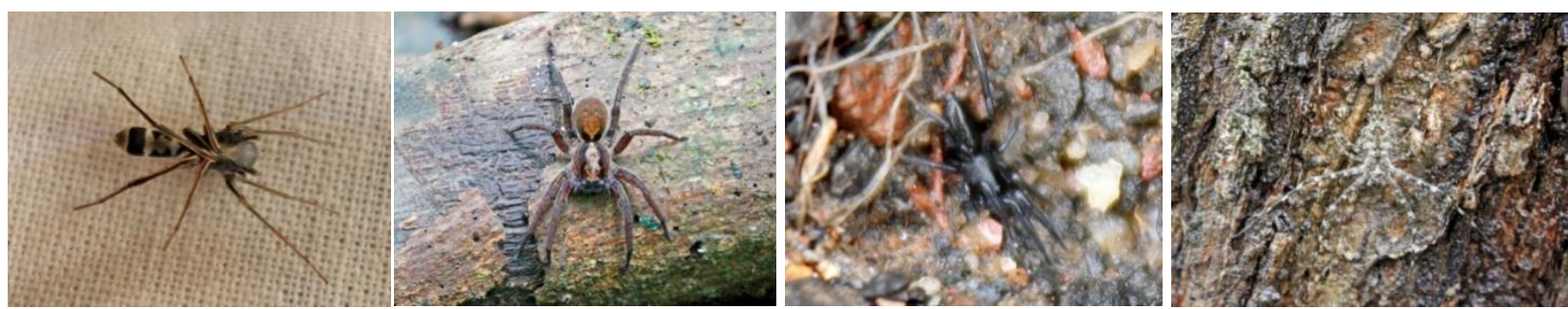

Photos 2: Corinnidae: Castianeira zetes, Ctenidae: Ctenus sp., Gnaphosidae: Zelotes sp., Hersiliidae: Hersilia savignyi.
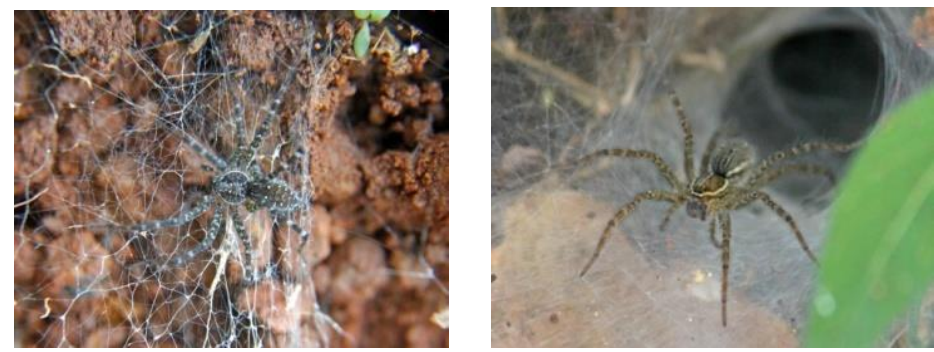

Photos 3: Lycosidae: Hippasa agelenoides, Hippasa pisaurina.
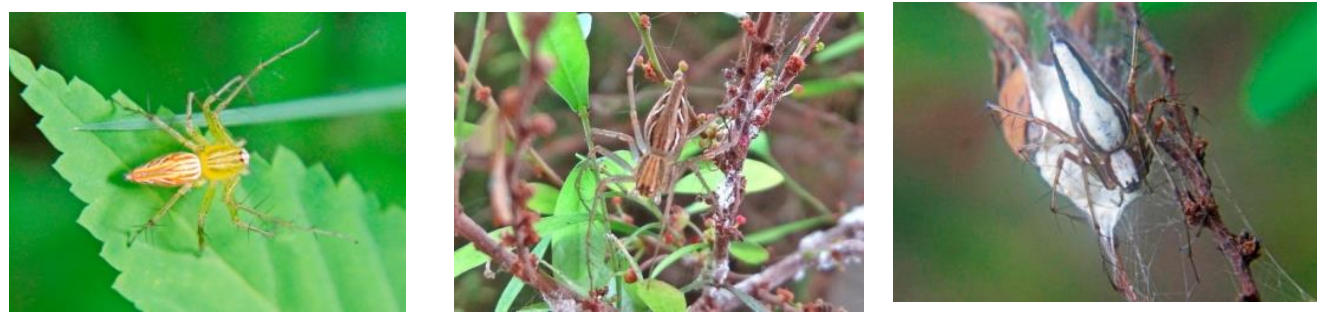

Photos 4: Oxyopidae: Oxyopes birmanicus, Oxyopes javanus, Oxyops shweta.
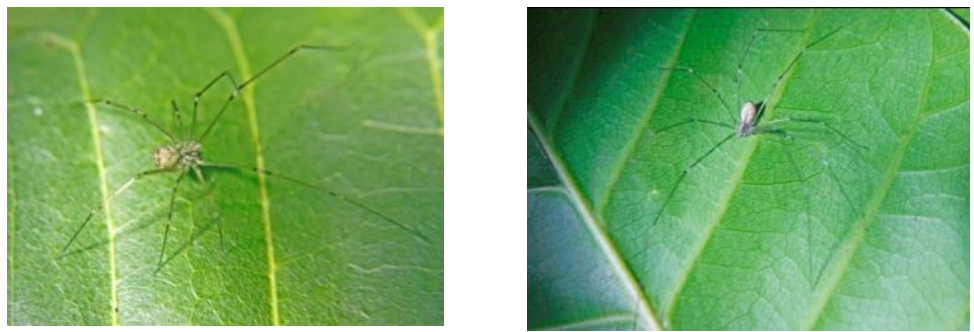

Photos 5: Pholcidae: Artema atlanta, Crossopriza lyoni. 

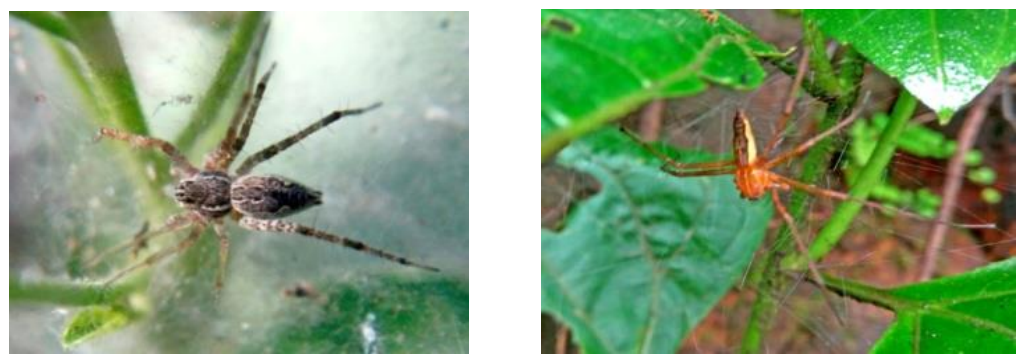

Photos 6: Pisauridae: Dendrolycosa gitae, Psecheridae: Psechrus sp.

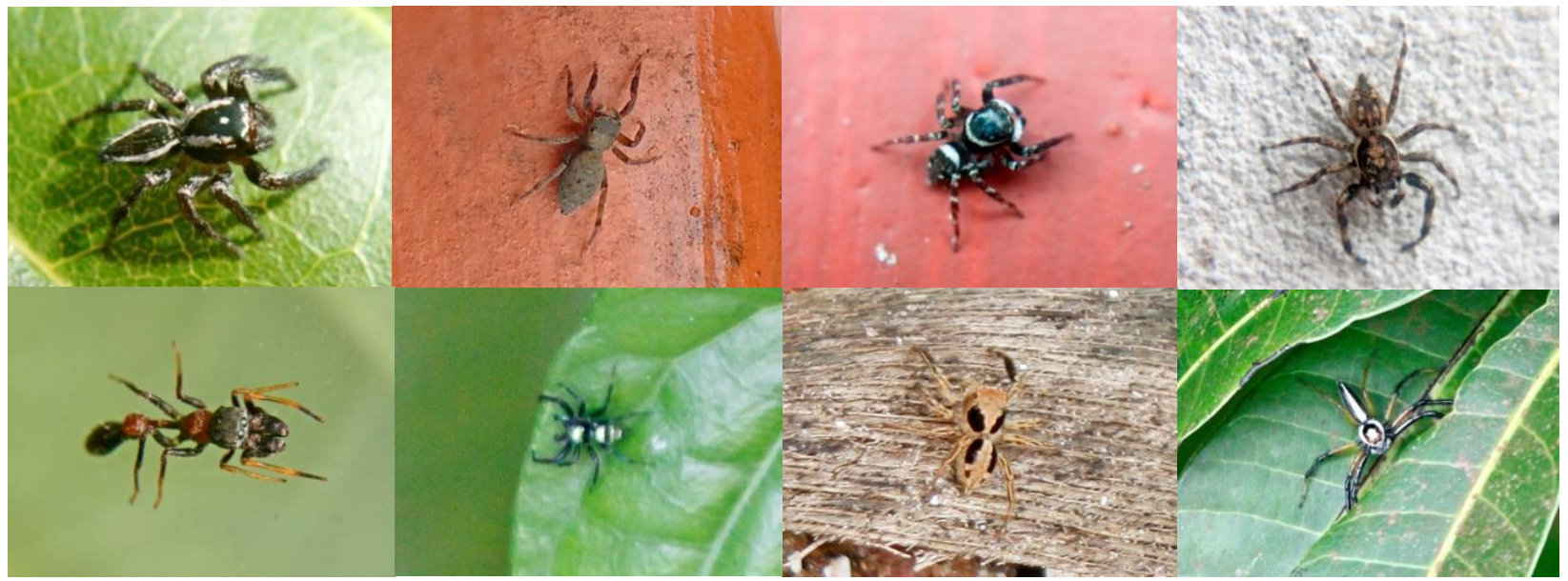

Photos 7: Salticidae: Carrhotus viduus, Cyrba ocellata, Hasarius adansoni, Menemerus bivitattus, Myrmarachne melanocephala, Phintella vittata, Plexippus petersi, Telamonia dimidiata.

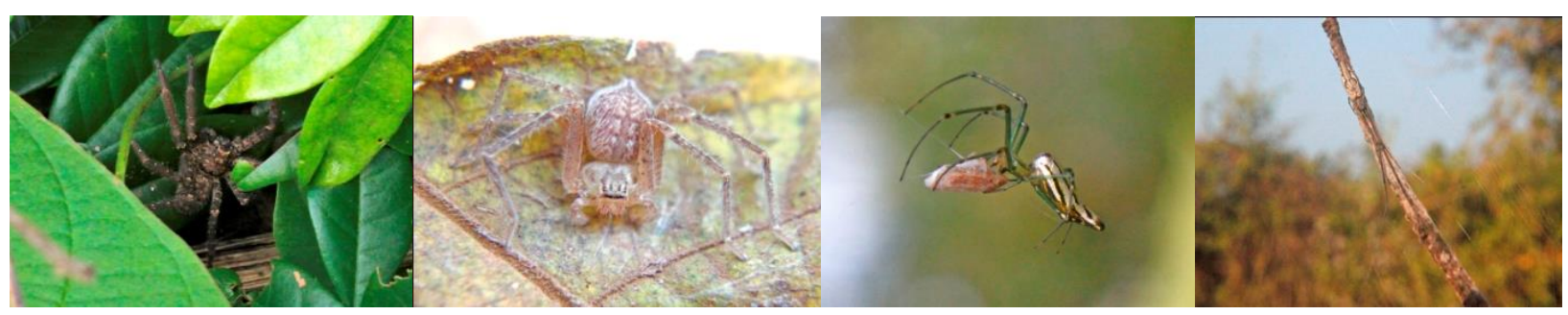

Photos 8: Sparassidae: Heteropoda sp., Olios sp., Tetragnathidae: Leucauge decorata, Tetragnatha sp.

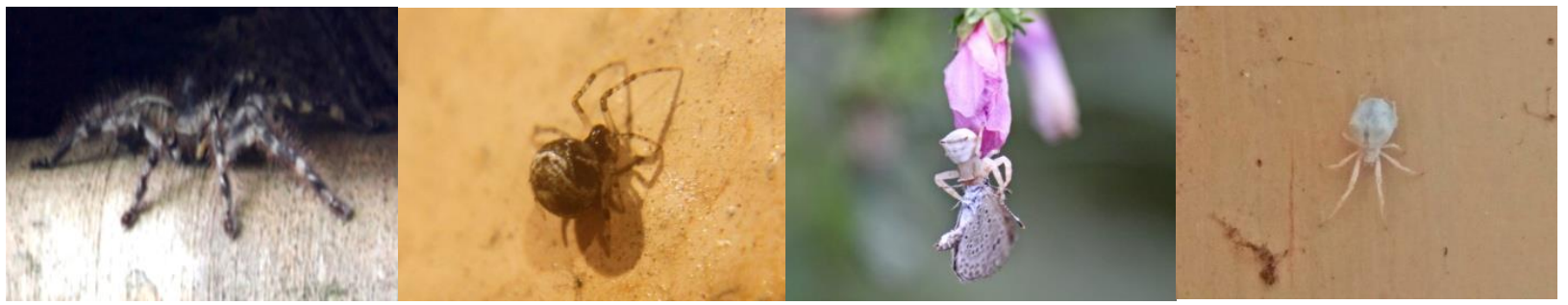

Photos 9: Theraphosidae: Poecilotheria regalis, Theridiidae: Achaearanea durgae, Thomisidae: Thomisus spectabilis, Uloboridae: Uloborus sp. 


\section{Result}

In this present study, a total of 74 species of spiders belonging to 44 genera distributed over 17 families were recorded (Table 1). It was surprising to find that the work covered only a small region, i.e. the Taleigao plateau with different sub-habitats, in the whole of Goa which is the smallest state of India, and has got the diversity that is $4.38 \%$ of Indian spiders.

\begin{tabular}{|c|c|c|c|c|}
\hline Sr.No. & Family & \multicolumn{2}{|c|}{ Spider Fauna Genus/Species } & Guild \\
\hline \multirow{16}{*}{1} & \multirow{16}{*}{ Araneidae } & & Araneus sp. & Orb Web Weavers \\
\hline & & 2. & Argiope anasuja (Thorell, 1887) & Orb Web Weavers \\
\hline & & & Argiope pulchella (Thorell, 1881) & Orb Web Weavers \\
\hline & & 4. & Cyclosa spirifera (Simon, 1889) & Orb Web Weavers \\
\hline & & 5. & Cyclosa sp. & Orb Web Weavers \\
\hline & & & Cyrtophora cicatrosa (Stoliczka, 1869) & Orb Web Weavers \\
\hline & & 7. & Eriovixia $\mathrm{sp}$. & Orb Web Weavers \\
\hline & & & Herennia multipuncta (Doleschall, 1859) & Orb Web Weavers \\
\hline & & 9. & Larinia sp. & Orb Web Weavers \\
\hline & & & Neoscona bengalensis (Tikader and Bal, 1981) & Orb Web Weavers \\
\hline & & & Neoscona mukerjei (Tikader, 1980) & Orb Web Weavers \\
\hline & & & Neoscona theisi (Walckenaer, 1906) & Orb Web Weavers \\
\hline & & & Neoscona sp. & Orb Web Weavers \\
\hline & & & Nephila kuhlii (Doleschall, 1859) & Orb Web Weavers \\
\hline & & & Nephila maculata (Simon, 1901) & Orb Web Weavers \\
\hline & & & Thelacantha sp. & Orb Web Weavers \\
\hline 2 & Corinnidae & 17. & Castianeira zetes (Simon, 1897) & Ground runners \\
\hline 3 & Ctenidae & 18. & Ctenus sp. & Other hunters \\
\hline 4 & Gnaphosidae & 19. & Zelotes sp. & Ground runners \\
\hline 5 & Hersiliidae & 20. & Hersilia savignyi (Lucas, 1836) & Foliage runners \\
\hline \multirow[t]{5}{*}{6} & \multirow[t]{5}{*}{ Lycosidae } & & Hippasa agelenoides (Simon, 1884) & Ground runners \\
\hline & & & Hippasa greenalliae (Blackwall, 1867) & Ground runners \\
\hline & & & Hippasa pisaurina (Pocock, 1900) & Ground runners \\
\hline & & & Pardosa sp. 1 & Ground runners \\
\hline & & & Pardosa sp. 2 & Ground runners \\
\hline \multirow[t]{4}{*}{7} & \multirow[t]{4}{*}{ Oxyopidae } & & Oxyopes birmanicus (Thorell, 1887) & Stalkers \\
\hline & & & Oxyopes javanus (Thorell, 1887) & Stalkers \\
\hline & & & Oxyopes shweta (Tikader, 1970) & Stalkers \\
\hline & & & Oxyopes sp. 1 & Stalkers \\
\hline
\end{tabular}




\begin{tabular}{|c|c|c|c|c|}
\hline & & 30. & Oxyopes sp. 2 & Stalkers \\
\hline & & 31. & Oxyopes sp. 3 & Stalkers \\
\hline & & 32. & Oxyopes sp. 4 & Stalkers \\
\hline 8 & \multirow{4}{*}{ Pholcidae } & 33. & Artema atlanta (Walckenaer, 1837) & Space web builders \\
\hline & & 34. & Crossopriza lyoni (Blackwall, 1867) & Space web builders \\
\hline & & 35. & Pholcus phalangioides (Fuesslin, 1775) & Space web builders \\
\hline & & 36. & Pholcus sp. & Space web builders \\
\hline 9 & Pisauridae & 37. & Dendrolycosa gitae (Tikader, 1970) & Ambushers \\
\hline 10 & Psechridae & 38. & Psechrus sp. & Sheet web weavers \\
\hline \multirow{22}{*}{11} & \multirow{22}{*}{ Salticidae } & 39. & Carrhotus viduus (C.L. Koch, 1846) & Stalkers \\
\hline & & 40. & Cyrba ocellata (Kroneberg, 1875) & Stalkers \\
\hline & & 41. & Cyrba sp. & Stalkers \\
\hline & & 42. & Hasarius adansoni (Audouin, 1826) & Stalkers \\
\hline & & 43. & Hyllus semicupreus (Simon, 1885) & Stalkers \\
\hline & & 44. & Langona sp. & Stalkers \\
\hline & & 45. & Menemerus bivitattus (Dufour, 1831) & Stalkers \\
\hline & & 46. & Menemerus sp. 1 & Stalkers \\
\hline & & 47. & Menemerus sp. 2 & Stalkers \\
\hline & & 48. & Menemerus sp. 3 & Stalkers \\
\hline & & 49. & Menemerus sp. 4 & Stalkers \\
\hline & & 50. & Menemerus sp. 5 & Stalkers \\
\hline & & 51. & Myrmarachne melanocephala (MacLeay, 1839) & Stalkers \\
\hline & & 52. & Phintella vittata (C.L. Koch, 1846) & Stalkers \\
\hline & & 53. & Phintella sp. & Stalkers \\
\hline & & 54. & Plexippus paykulli (Audouin, 1826) & Stalkers \\
\hline & & 55. & Plexippus petersi (Karsch, 1878) & Stalkers \\
\hline & & 56. & Plexippus sp. 1 & Stalkers \\
\hline & & 57. & Plexippus sp. 2 & Stalkers \\
\hline & & 58. & Plexippus sp. 3 & Stalkers \\
\hline & & 59. & Stenaelurillus sp. & Stalkers \\
\hline & & 60. & Telamonia dimidiata (Simon, 1899) & Stalkers \\
\hline \multirow[t]{2}{*}{12} & \multirow[t]{2}{*}{ Sparassidae } & 61. & Heteropoda sp. & Foliage runners \\
\hline & & 62. & Olios sp. & Foliage runners \\
\hline \multirow[t]{2}{*}{13} & \multirow[t]{2}{*}{ Tetragnathidae } & 63. & Leucauge decorata (Blackwall, 1864) & Orb Web Weavers \\
\hline & & 64. & Leucauge sp. & Orb Web Weavers \\
\hline
\end{tabular}




\begin{tabular}{|l|l|ll|l|}
\hline \multirow{2}{*}{} & \multirow{2}{*}{} & 65. & Tetragnatha sp. 1 & Orb Web Weavers \\
\cline { 3 - 5 } & & 66. & Tetragnatha sp. 2 & Orb Web Weavers \\
\cline { 3 - 5 } & 67. & Tylorida sp. & Orb Web Weavers \\
\hline 14 & Theraphosidae & 68. & Poecilotheria regalis (Pocock, 1899) & Sensing web weavers \\
\hline 15 & Theridiidae & 69. & Achaearanea durgae (Tikader, 1970) & Space web builders \\
\hline 16 & \multirow{2}{*}{ Thomisidae } & 70. & Stiphropus sp. & Ambushers \\
\cline { 3 - 5 } & & 71. & Synema sp. & Ambushers \\
\cline { 3 - 5 } & & 72. & Thomisus spectabilis (Doleschall, 1859) & Ambushers \\
\hline 17 & Uloboridae & 73. & Uloborus sp. 1 & Orb Web Weavers \\
\hline & & 74. & Uloborus sp. 2 & Orb Web Weavers \\
\hline
\end{tabular}

Table 1: A complete checklist of spiders obtained during the study on Taleigao Plateau.

\subsection{Family diversity}

17 families were reported representing $27.9 \%$ of 61 families in India. The most dominant family recorded during the present research was Salticidae followed by Araneidae. The least number of species was recorded in families Corinnidae, Ctenidae, Hersiliidae, Pisauridae, Psechridae and Theraphosidae (Graph 1).

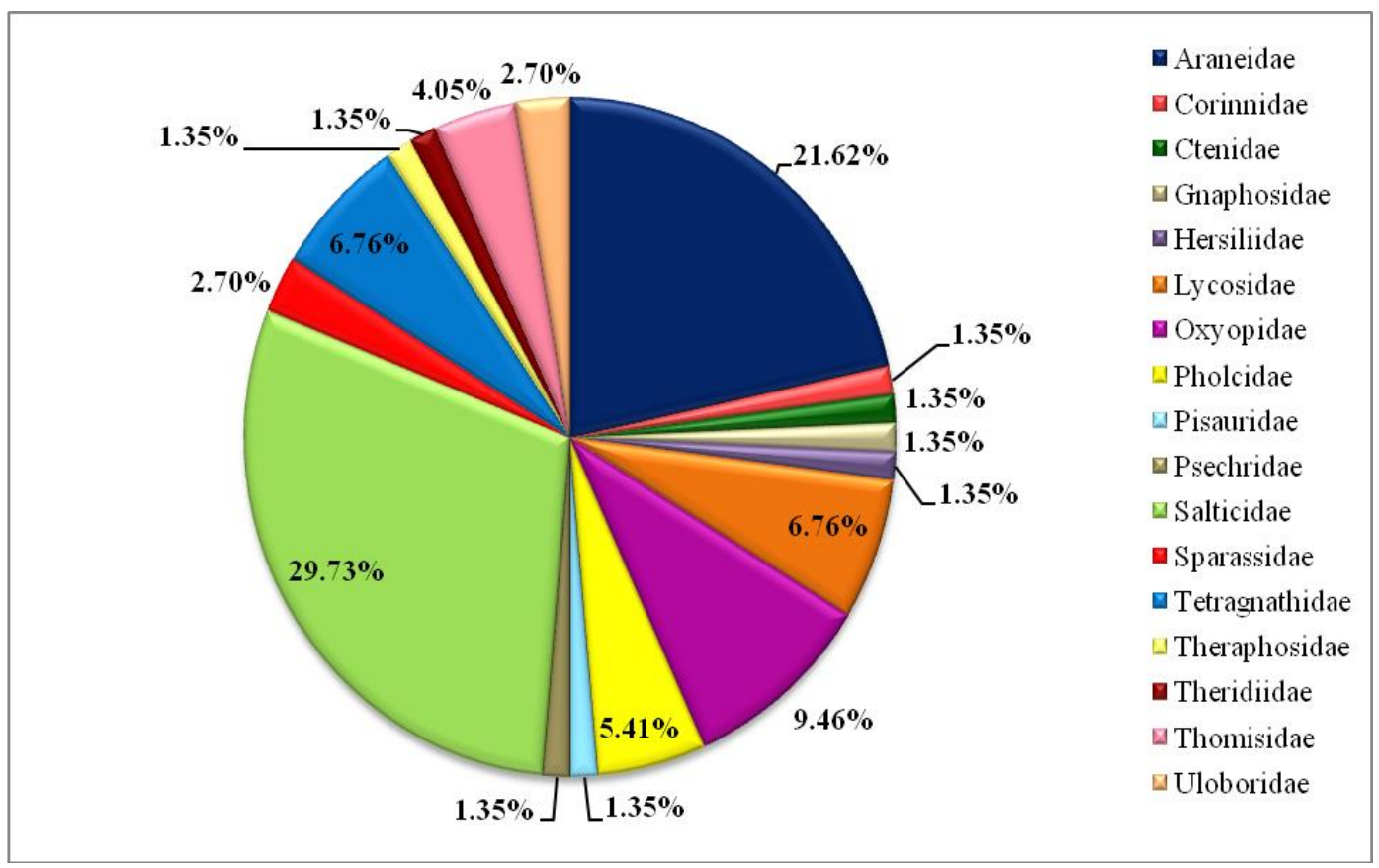

Graph 1: Percentile distribution of spider families. 


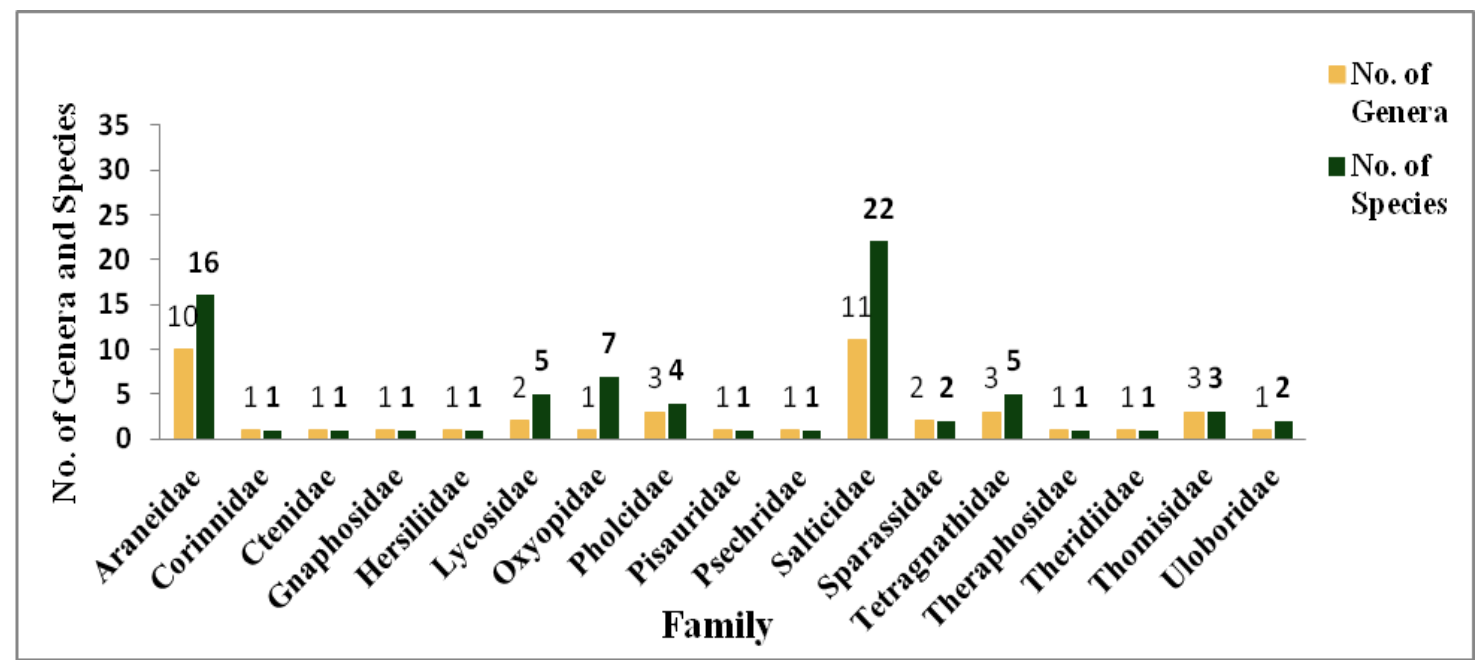

Graph 2: Comparative distribution of generic and species diversity of spiders in different families.

\subsection{Generic diversity}

India represents 438 genera from which 44 genera were recorded during the study. This accounts for $10.04 \%$ of the genera found in India. Highest generic diversity was found in Salticidae (11), Araenidae (10), Tetragnathidae (3), Pholcidae (3), Thomisidae (3), Lycosidae (2), Sparassidae (2), and Corinnidae, Ctenidae, Hersiliidae, Gnaphosidae, Oxyopidae, Pisauridae, Psechridae, Theraphosidae, Theridiidae, Uloboridae were with 1 genera each (Graph 2). The number of genera is higher than those in, Sikkim-33 [15] and Andaman and Nicobar Island-41 [16].

\subsection{Species diversity}

Though India accounts with 1686 species of spiders, present report of 74 species recorded from the 296 ha area surveyed, accounts for $4.38 \%$ of reported Indian spider species, which is quite high (Graph 2). Maximum richness was observed with respect to species Hersilia savignyi, Oxyopes javanus, Artema atlanta, Hasarius adansoni, Menemerus bivitattus, Plexippus paykulli and Plexippus petersi.

\subsection{Endemism}

A total of 252 endemic species of spiders are reported from India so far [17]. Among the 74 species, on the Taleigao plateau, 5 species, Cyclosa spirifera, Neoscona bengalensis, Neoscona mukerjei, Achaearanea durgae and Poecilotheria regalis are endemic to India whereas Argiope anasuja, Castianeira zetes, Hyllus semicupreus are endemic to South Asia. Crossopriza lyoni, Pholcus phalangioides, Hasarius adansoni, Plexippus paykulli are cosmopolitan and the remaining spiders are mostly endemic to South East Asia and to the Continent Asia.

\subsection{New record of a primitive spider for the state}

So far from Goa, only one family viz., Theraphosidae under suborder Mygalomorphae has been reported [8]. But, during the present investigations another member viz., Poecilotheria regalis, which happens to be a new record for 
the state of Goa was recorded. Earlier reports indicate that, this species was found in Kerala, Karnataka and Tamil Nadu [18].

\subsection{Guild Classification}

The spider guild classification was composed according to the families reported during the study. The spiders were classified into 9 ecological guilds based on their foraging mode (Graph 3).

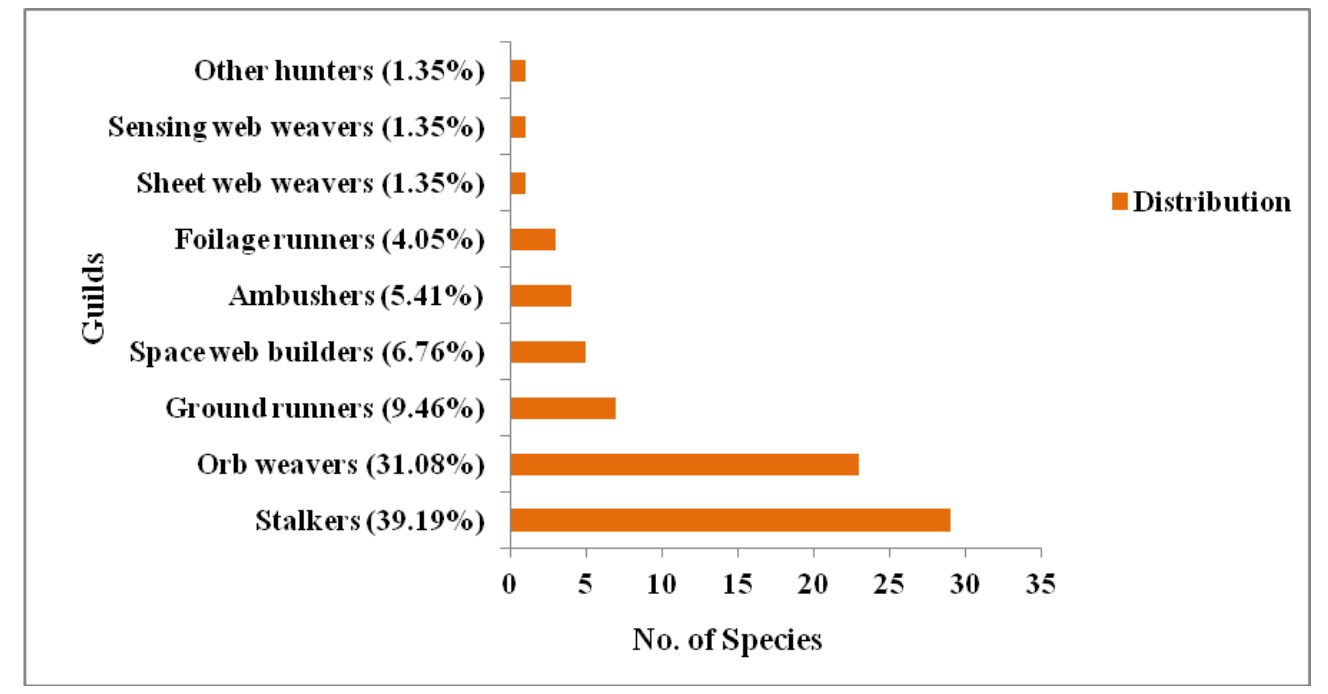

Graph 3: Guild structure of spiders.

\section{Discussion}

In the study of spider diversity in Taleigao which lasted for just 8 months, it was attention grabbing to find various types of spiders flourishing in this small area with $27.9 \%$ of spider families and $4.38 \%$ spider species. Nearly $88 \%$ of all the species recorded through this work, for the Taleigao plateau, are new additions to the checklist of the state over the earlier report [8].

The high diversity was found to be mainly due to the habitat and the environment. Taleigao plateau is endowed with different types of habitats and comprises of dense vegetation with splendid variety of flora and fauna. The diversity of spider indicates the presence of its associates especially insects. Insects are the main prey base for spiders [19]. The rich floral and faunal diversity is the key to build the microhabitat of different species of spiders [3].

Vegetation architecture also plays a major role in the species composition found within a habitat [20, 21, 22] and vegetation which is structurally more complex can sustain higher abundance and diversity of spiders [23, 22]. Hence complex vegetation and structural diversity on the plateau explain the occurrence of different guild structures. The various guilds also provide an understanding of disturbances and habitat modification on spiders.

Humidity and temperature affects the distribution of spiders as it influences the growth, development and activity $[24,25]$. Since spiders normally have preferences on humidity and temperature $[26,25]$, these factors limit them to 
areas within the range of their physiological tolerances. The high rate of transpiration by plants on the plateau area makes the atmosphere humid. Because of this complex interaction of various climatic factors like rainfall, temperature, availability of water source nearby, this area holds many smaller but diverse environmental niches.

Canopy and litter in some areas of the plateau additionally offer greater survival opportunities in the form of ecological niches. The plateau thus offers arthropods appropriate environment with favorable factors that support the rich spider diversity of the plateau. On this account, the study establishes that diversity normally increases when a greater variety of habitat types are present $[27,25]$ and the physical structure and species composition of vegetation define diversity of species and abundance through habitat availability [28, 25].

\section{Conclusion}

Taxonomy of spiders is an ambiguous area and consolidated data is lacking. Insufficient information in ecology and taxonomy of Indian spiders lowers the use of spiders as indicators species [29, 30]. Spiders of Goa are not studied enough with an extensive account of spider fauna being unavailable. This research has yielded new records of families, genera and species of spiders for the state of Goa. Several species of spiders are photographed for the first time in Goa and this digital data will be useful for the studies in future.

The investigation has thus proved to be invaluable as it has helped in creating a database bank, for holding information regarding distribution and diversity of these species, serving as baseline information to the ecology and the importance of spiders of this area. At the same time, the study has also shown that the Taleigao plateau habitat with its favorable vegetation and climate provides an ideal location for the growth and diversity of spiders. But the current development trend on the plateau can destroy the original lateritic mosaic. Therefore, documenting the spider diversity pattern on this plateau has provided data to justify the conservation of this ecosystem, as spiders are sensitive and are easily affected due to habitat damage resulting from anthropogenic activities.

\section{Acknowledgement}

The authors are grateful to Mr. Mangirish Dharwadkar, Wildlife and Eco-tourism Wing, Goa Forest Department, Mr. John Caleb, research associate at the Zoological Survey of India and Mr. Atish Gawai, an Arachnid expert, for their expertise in identification and taxonomy of Spiders.

\section{References}

1. Coddington JA, Colwell RK. Arachnids. Encyclopedia of biodiversity 1 (2001): 199-218.

2. Coddington JA. Phylogeny and classification of spiders. Spiders of North America: An Identification Manual, American Arachnological Society (2005): 18-23.

3. Chetia P, Kalita DK. Diversity and distribution of spiders from Gibbon Wildlife Sanctuary, Assam, India. Asian Journal of Conservation Biology 1 (2012): 5-15. 
4. Hore U. Diversity and structures of spider assemblages in Terai Conservation Area. Thesis PhD, Saurashtra University (2009): 1-221.

5. Anonymous. World Spider Catalog, Natural History Museum Bern (2017).

6. Keswani S, Hadole P, Rajoria A. Checklist of Spiders (Arachnida: Araneae) from India-2012. Indian Journal of Arachnology 1 (2012): 1-129.

7. Roy TK, Saha S, Raychaudhuri D. Spider Fauna of Meghalaya, India. Biodiversity: Exploration, Exploitation, Conservation and Management - Vision and Mission. Proc. UGC Sponsored National Seminar, Kolkata, India. World Scientific News 71 (2017): 1-228.

8. Bastawade DB, Borkar M. Arachnida Orders scorpiones, uropygi, amblypygi, araneae and phalangida. Zool. Surv. India, Fauna of Goa, State Fauna Series 16 (2008): 211-242.

9. Uniyal VP, Sivakumar K, Quasin S. Diversity of Spiders in Nanda Devi Biosphere Reserve. Wildlife Institute of India, Dehradun (2011): 1-199.

10. Joshi V, Janarthanam MK. The diversity of life form type, habitat preference and phenology of endemics in Goa region of the Western Ghats, India. Journal of Biogeography 31 (2004): 1227-1237.

11. Watve A. Vegetation on rock outcrops in Northern Western Ghats and Konkan region, Maharastra. Geobios 30 (2003): 41-46.

12. Desai M, Shanbhag AB. An Avifaunal Case Study of a Plateau from Goa, India: An Eye Opener for Conservation of Plateau Ecosystems. Journal of Threatened Taxa 4 (2012): 2444-2453.

13. Tikader BK. Handbook of Indian Spiders (Ed: Anon). Zoological Survey of India, Calcutta (1987): 1-251.

14. Sebastian PA, Peter KV. Spiders of India. Universities Press Pvt. Ltd. (2009): 1- 614.

15. Tikader BK. Spider fauna of Sikkim. Records of the Zoological Survey of India 64 (1970): 1-83.

16. Tikader BK. Studies on spider fauna of Andaman and Nicobar islands, Indian Ocean. Records of Zoological Survey of India 72 (1977): 153-212.

17. Siliwal M, Molur S, Biswas BK. Indian Spiders (Arachnida: Araneae): Updated Checklist $2005 . \quad$ Zoos' Print Journal 20(10) (2005): 1999-2049.

18. Dhali DC, Sureshan PM, Chandra K. Diversity and Distribution of Indian Primitive Spiders (Araneae: Opisthothelae: Mygalomorphae) in different state including an Annotated Checklist. World Scientific News 37 (2016): 88-100

19. Sebastian PA, Peter KV. Spiders of India. Universities Press, India (2012): 1-395.

20. Greenstone MJ. Determinants of Web Spider Species Diversity: Vegetation Structural Diversity vs. Prey Availability. Oecologia 62 (1984): 299-304.

21. Scheidler M. Influence of Habitat Structure and Vegetation Architecture on Spiders. Zoologischer Anzeiger 225 (1990): 333-340.

22. Sudhikumar AV, Mathew MJ, Sunish E, Sebastian PA. Seasonal Variation in Spider Abundance in Kuttanad Rice Agro-Ecosystem, Kerala, India (Araneae). European Arachnology, Acta zoologica bulgarica 1 (2005): 181-190. 
23. Hatley CL, Macmahon JA. Spider Community Organization: Seasonal Variation and the Role of Vegetation Architecture. Environmental Entomology 9 (1980): 632-39.

24. Hodkinson ID. Terrestrial Insects along Elevation Gradients: Species and Community Responses to Altitude. Biological Review 80 (2005): 489-513.

25. Lalisan JA, Dupo ALB, Nuneza OM. Diversity of spiders along an elevational gradient in Mt. Pinukis, Zamboanga del Sur, Philippines. Journal of Biodiversity and Environmental Sciences 7 (2015): 190-201.

26. Riechert SE, Gillespie RG. Habitat Choice and Utilization in the Web Spinners. In Spiders-Webs, Behavior And Evolution. Stanford University Press, Stanford, California (1986): 23-48.

27. Reid WV, Miller KR. Keeping Options Alive: The Scientific Basis for Conserving Biodiversity. Washington D.C., World Resources Institute (1989).

28. Malumbres-Olarte J, Vink CJ, Ross JG, et al. The Role of Habitat Complexity on Spider Communities in Native Alpine Grasslands of New Zealand. Insect Conservation and Diversity 6 (2013): 124-134.

29. Kapoor V. Effects of Rainforest Fragmentation And Shade-Coffee Plantations on Spider Communities in the Western Ghats. India. J. Insect Conserv 12 (2008): 53-68.

30. Noss RF. Indicators for Monitoring Biodiversity: A Hierarchical Approach. Conservation Biology 4 (1990): 355-364.

(C) This article is an open access article distributed under the terms and conditions of the Creative
Commons Attribution (CC-BY) license 4.0 